IRA-International Journal of Education \& Multidisciplinary Studies

ISSN 2455-2526; Vol.13, Issue 03 (December, 2018)

Pg. no. 41-47.

Institute of Research Advances

Institute of

http://research-advances.org/index.php/IJEMS

\title{
A Comparative Study of the Negative Transfer of Mother Language in English Grammar Teaching
}

\author{
CHENG Dai-hong $^{1 \#}$, PAN Cui-qiong ${ }^{2}$ \\ ${ }^{1,2}$ Yangtze University, Hubei Jingzhou 434020, China. \\ \#corresponding author. \\ Type of Review: Peer Reviewed. \\ DOI: http://dx.doi.org/10.21013/jems.v13.n3.p2
}

\section{How to cite this paper:}

Dai-hong, C., Cui-qiong, P. (2018). A Comparative Study of the Negative Transfer of Mother Language in English Grammar Teaching. IRA International Journal of Education and Multidisciplinary Studies (ISSN 2455-2526), 13(3), 41-47.doi: http://dx.doi.org/10.21013/jems.v13.n3.p2

(C) Institute of Research Advances.

This work is licensed under a Creative Commons Attribution-Non Commercial 4.0 International License subject to a proper citation to the publication source of the work.

Disclaimer: The scholarly papers as reviewed and published by the Institute of Research Advances (IRA) are the views and opinions of their respective authors and are not the views or opinions of the IRA. The IRA disclaims of any harm or loss caused due to the published content to any party.

Institute of Research Advances is an institutional publisher member of Publishers Inter Linking Association Inc. (PILA-CrossRef), USA. The institute is an institutional signatory to the Budapest Open Access Initiative, Hungary advocating the open access of scientific and scholarly knowledge. The Institute is a registered content provider under Open Access Initiative Protocol for Metadata Harvesting (OAI-PMH).

The journal is indexed \& included in WorldCat Discovery Service (USA), CrossRef Metadata Search (USA), WorldCat (USA), OCLC (USA), Open J-Gate (India), EZB (Germany) Scilit (Switzerland), Airiti (China), Bielefeld Academic Search Engine (BASE) of Bielefeld University, Germany, PKP Index of Simon Fraser University, Canada. 


\begin{abstract}
It is the normal phenomenon that Chinese students' English grammar learning may badly be influenced by mother language transfer. Especially the negative transfer must hinder the students' progress in English learning. How to overcome the negative transfer becomes very crucial. This paper analyzes the negative transfer effects on English grammar teaching from the comparative perspectives of part of speech and sentence structure between English and Chinese, which provides enlightenment for students' English grammar learning, and also provides feasible countermeasures for teachers' English grammar teaching in such way as to promote students' comprehensive English ability.
\end{abstract}

Key-words: mother tongue transfer; the negative transfer; English grammar teaching

\title{
1.Introduction
}

Transfer is the concept of psychology and refers to the effect of one kind of learning to another. Foreign language learners transfer the characteristics and structures of their mother tongue to foreign language acquisition, and this is called mother tongue transfer. Later, in the study of language, the theory of language learning transfer emerged which means that learners are influenced by their existing language knowledge and skills in the learning of new language knowledge and skills. Transfer in language learning is divided into the positive and negative transfer. When the language learner's existing knowledge promotes the learning of the new language, a positive transfer of the language occurs. Conversely, when the learner's existing knowledge hinders or interferes with the learning of the new language, a negative transfer occurs. Ellis (1970) said, "Any second language acquisition theory that does not describe the transfer of the mother tongue is incomplete." Pica (1994) listed "how the mother tongue affects second language acquisition" as one of the top ten issues that foreign language teaching people are most concerned about, that is, the role and influence of mother tongue on second language acquisition cannot be ignored. So, this paper mainly discusses the influence of negative transfer of mother tongue in English grammar teaching, which helps us understand the differences between English and Chinese grammar, avoid the negative transfer, and provide effective guidance for English teachers' English grammar teaching.

\section{English Grammar Features}

\subsection{English grammar system}

The English grammar system is mainly composed of word class, sentence class, tense, voice, tone, sentence component, sentence structure and clause. ( Table 1 )

Table 1 English grammar system

\begin{tabular}{|c|l|}
\hline Parameters & \multicolumn{1}{c|}{ Components } \\
\hline Word Class & $\begin{array}{l}\text { noun, pronoun, numeral, verb, adjective, adverb, article, preposition, conjunction, } \\
\text { interjection, noun }\end{array}$ \\
\hline Sentence Class & $\begin{array}{l}\text { declarative sentence, interrogative sentence, imperative sentence, exclamatory } \\
\text { sentence, simple sentence, parallel sentence, compound sentence }\end{array}$ \\
\hline Tense & $\begin{array}{l}\text { simple present tense, simple past tense, simple future tense, present progressive } \\
\text { tense, past progressive tense, future progressive tense, present perfect tense, past } \\
\text { perfect tense, future perfect tense, present perfect progressive tense, past perfect } \\
\text { progressive tense, future perfect progressive sense, simple past future tense, past } \\
\text { future progressive tense, past future perfect tense, past future perfect progressive } \\
\text { tense }\end{array}$ \\
\hline
\end{tabular}




\begin{tabular}{|c|l|}
\hline Voice & active voice, passive voice \\
\hline Tone & declarative tone, imperative tone, subjunctive tone \\
\hline Sentence Component & subject, predicate, object, attributive, complement, adverbial, predicative \\
\hline Sentence Structure & simple sentence, parallel sentence, compound sentence \\
\hline Clause & $\begin{array}{l}\text { noun clause, subject clause, object clause, predicative clause, appositive clauses, } \\
\text { other clauses }\end{array}$ \\
\hline
\end{tabular}

\subsection{English and Chinese grammar differences}

English and Chinese have essential differences in the form of words and the formation of sentences. They are mainly showed in word class and syntax.

\subsubsection{Word class}

The differences between English and Chinese in word classes are mainly presented in verbs, nouns and articles.

Verbs in English can be divided into "tense" and "aspect", indicating present, past and future with strict characteristics. In addition, there are active voices and passive voices in English. However, there is no specific tense in Chinese, but it can also be divided into active sentences and passive sentences, which are ambiguous and uncertain.

Nouns in English have the distinction between countable nouns and uncountable nouns, and countable nouns can be divided into singular and plural numbers. However, nouns in Chinese are almost identical in the singular and plural which only differs from the singular by attaching the Chinese character “们”.

Articles in English are divided into definite articles, indefinite articles (a/an) and zero articles, but there is no article in Chinese word classes.

\subsubsection{Syntax}

The differences between English and Chinese in syntax are mainly showed in sentence structures and word orders. ( Table2)

Table2 English-Chinese syntax differences

\begin{tabular}{|c|c|c|c|}
\hline \multirow[t]{2}{*}{ Sentences } & \multirow[t]{2}{*}{ Structural features } & \multicolumn{2}{|c|}{ Word orders } \\
\hline & & Modifiers & $\begin{array}{c}\text { Inverted } \\
\text { Sentences }\end{array}$ \\
\hline English sentences & $\begin{array}{l}\text { use long sentences, main clauses and subordinate } \\
\text { clauses distinguished clearly, use passive sentences } \\
\text { commonly }\end{array}$ & $\begin{array}{l}\text { flexible position, } \\
\text { be placed before } \\
\text { or after the } \\
\text { modified } \\
\text { component }\end{array}$ & $\begin{array}{l}\text { fixed position, } \\
\text { be placed before } \\
\text { the modified } \\
\text { component }\end{array}$ \\
\hline Chinese sentences & $\begin{array}{l}\text { use short sentences, no main clauses sometimes, use } \\
\text { active sentences commonly }\end{array}$ & $\begin{array}{l}\text { use full inversion } \\
\text { and partial } \\
\text { inversion } \\
\text { commonly }\end{array}$ & $\begin{array}{l}\text { use partial } \\
\text { inversion } \\
\text { commonly }\end{array}$ \\
\hline
\end{tabular}


Because of these differences, students have a negative transfer when learning English grammar.

\section{Negative Transfer of Chinese in English Grammar Learning}

The negative influence of Chinese on English grammar learning is mainly reflected in the word class and syntax.

\subsection{Word class}

The negative influence of Chinese on English word class learning is mainly demonstrated in verbs, nouns and articles.

\subsubsection{Verbs}

The differences in the usage of verbs between English and Chinese have been explained above, especially in tense. For example, “玛丽正在看电视。” and “昨天下午两点, 玛丽正在看电视。”, both of them have the word “正在” in the sentences, but the time is completely different. The English expressions of these two sentences are respectively "Mary is watching TV." and "Mary was watching TV at 2 pm yesterday.", and the former is present progressive tense while the latter is past progressive tense. For another example, Chinese sentence “他周六要去游泳。” and its corresponding English expression “He will go swimming on this Saturday." There is no obvious tense expression in Chinese sentence, but the structure "will go" is that of "will + the original form of a verb" and it is the past future tense obviously. Therefore, a negative transfer occurs in the use of verbs.

\subsubsection{Nouns}

In English, if a noun means a thing or something, a singular form should be used, such as dog, flower, building, etc. However, if two or more are expressed, the plural form of the noun is needed, such as dogs, flowers, buildings, etc. And the singular and plural forms of the countable nouns are also different in the agreement with the verbs of sentences. But in Chinese, word-ending character “...们” is a symbolic plural form to describe somebody, such as “孩子们”, “姐妹们”, “领导们”, etc, there is no distinction between them in the concord with their verbs in sentences.

Because of this, English learners are influenced by the negative transfer of Chinese when they meet with something involved in countable nouns and uncountable nouns, and singular and plural problems in countable nouns are also ignored or forgotten.

\subsubsection{Articles}

In English, a definite article is used to define the following nouns as a specific thing or refer to something that has mentioned above, such as "the books", "the apple", etc. An indefinite article is used to mean that the following noun refers to one of a certain class of specific things, such as "a book", "an apple", etc. A zero article refers to a kind of situation where no article is needed, to which somebody or something can be referred in a general sense. In Chinese, however, there are no definite articles, indefinite articles and zero articles.

Because the three types of articles in English are distinct and there is no specific article in Chinese, students often make the following mistakes due to the negative transfer of Chinese: (1) Use articles when they are not needed. For example, "They often go to school by the bus."In this sentence, the definite article is used incorrectly and is not needed. It is known that definite articles are not needed in before the nouns of a certain 
vehicle. (2) Use the definite article "the" when the indefinite article should be used. For example, "Geography also plays the part in making dialects."In this sentence, the definite article is used incorrectly and indefinite article "a" should be needed. As we all know, indefinite articles should be used in some idiomatic usages. (3) Use the indefinite article "a/an" when the definite article should be used. For example, "She has played a piano since the age of six." In this sentence, the indefinite article is used incorrectly and definite article "the" should be needed. It is known that indefinite articles are needed before the nouns of a certain musical instruments. (4)Not use articles when they are needed. For example, "Is this first time you have visited Beijing?" In this sentence, zero article is used incorrectly and a definite article "the" should be placed before "first time". As we all know, definite articles are needed before ordinal numbers.

\subsection{Syntax}

The negative influence of Chinese on English syntax learning is mainly reflected in sentence structures, active sentences and passive sentences.

\subsubsection{Sentence structures}

English sentences are relatively complete, and long sentences are often used. An English sentence may consist of a main sentence plus a clause, even more than one clause sometimes. However, Chinese sentence patterns sometimes have no subject or no main sentence, and often use short sentences. There is no clear distinction between the main sentence and clause. For example, (1) "I asked him whether he was a lawyer." This English sentence is formed by a main sentence plus a clause. In it, "I" is subject, "asked" is predicate and "him" is an object, so in this sentence, "I asked him" is its main sentence and "whether he was a lawyer" is its object clause. (2) "I didn't realize how special my father was until I became an adult." It is obvious that this is an English sentence pattern and it is formed by the main sentence and two clauses. In it, "I" is subject, "didn't realize" is a predicate, so in this sentence, "I didn't realize" is its main sentence, "how special my father was" is its object clause and "until I became an adult" is its temporal adverbial clause. However, in Chinese sentence patterns, for example, (1)“散会了。”, and its English expression is “The meeting is over.” There is no subject in this Chinese sentence while the obvious subject "The meeting" is in the English sentence. It also shows the feature of non-subject Chinese sentences and proves that short sentences are often used in Chinese sentences. (2)“商标法规定, 在商品包装上出现企业名称和地址时, 应当使用汉字或汉字, 汉语拼音并用, 不能单 独使用汉语拼音。”, and its English expression is “The Trademark Law stipulates that when the company name and address appear on the commodity packaging, Chinese characters or Chinese characters and Pinyin should be used together. Pinyin cannot be used alone.” In the Chinese sentence, “规定” is its predicate and its object is formed by a sentence, so it is called a kind of Chinese sentence pattern which is non-main sentence. However, there is the main sentence "The Trademark Law" in the corresponding English sentence obviously.

Because these differences between English and Chinese sentences, when students meet with long or difficult sentences and all kinds of clauses in the process of learning English grammar, wrong sentence expressions will appear.

\subsubsection{Active sentences and passive sentences}

An active sentence is a sentence in which the subject of the sentence is the sender of the action behavior done by the predicate. And a passive sentence is a sentence in which the subject of the sentence is the bearer of the action behavior done by the predicate. There are a lot of passive sentences because the focus and observation of English are often placed on the bearers of action. For example, "Chinese is spoken by many people." Here, 
"Chinese" is the bearer of the verb "speak". Compared with its Chinese expression, it reflects that more passive sentences are used in English sentence patterns. On the contrary, Chinese people are used to think, understand, explain and describe things in the objective world from the perspective of oneself, so active sentences are more common. For example, the above sentence may be said in Chinese “许多人讲英语。”Also “这本小说是海明威 写的。” is in English like “This novel was written by Hemingway.”

It is preciously because "the English and Chinese are different in thinking mode and expression habits, so English passive sentences are used much more frequently than Chinese passive sentences." (Cao Guihua, 2010: 30). Because of the negative transfer of Chinese, students have great difficulties in learning English active and passive sentences.

\section{The Enlightenment of Mother Tongue Transfer on English Grammar Teaching}

From the above discussion, we can see the negative influence of the mother tongue on the English in terms of word class and syntax learning.

As an English teacher, we must fully realize the difference between English and Chinese, realize the influence of Chinese on students' English grammar learning and negative transfer of the mother tongue, and guide students to find out solutions to eliminate and avoid English grammar mistakes caused by the negative transfer of the mother tongue.

\subsection{Word class concerned}

When English teachers teach the "tense" of English verbs, they can distinguish the past tense, present tense and future tense by drawing the timeline, so that students can establish a clear sense of English in a clear tense.

When English teachers teach the "aspect" of English verbs, they can compare the patterns of English and Chinese sentences, and let students memorize some passive voice patterns commonly used in English, such as "It is said that ...", "It is reported that ...", so that students can realize the characteristics of passive voice in English sentence patterns.

When English teachers teach English nouns, they can use the method of tree diagram classification and list column induction to guide students to distinguish countable nouns and uncountable nouns in English, as well as singular and plural in countable nouns.

When English teachers teach articles, they can give examples to illustrate the conditions under which definite articles, indefinite articles and zero articles are used, and summarize the rules.

\subsection{Syntax concerned}

When English teachers explain the structure of English sentence patterns, they can give more examples of using long sentences, main sentences and clauses in English, and lead students to divide sentence components together, familiar with and accustomed to the expression of English sentence patterns.

When English teachers explain passive voices, they can make students understand the characteristics of the passive voices in English by comparing and distinguishing the active and passive sentences of the same sentence. 
In a word, English teachers should be the guides of students' English grammar learning, and guide students to master the differences between English and Chinese grammar and overcome the influence of negative transfer of their mother tongue.

\section{Conclusion}

In the process of English learning, the promotion and interference of mother tongue exist all the time, especially in the study of English grammar. Therefore, in the process of English grammar teaching, teachers should actively guide students to make the differential contrast between English and Chinese through appropriate methods, overcome the influence of negative transfer of their mother tongue, and promote the study of English grammar. In addition, as an English teacher, we should always correct the students' attitude towards their mother tongue. By means of the English-Chinese comparison, we do not mean to get rid of the mother tongue in English language learning, we do mean that we need to try to eliminate and avoid interference of mother language and to promote students' English learning and teachers' English grammar teaching.

\section{References:}

[1]. (A)Teresa Pica. Questions from the language classroom: Research perspectives[J], TESOL Quarterly, 1994.

[2]. (E)Rod Ellis. Second Language Acquisition Research [M]. Shanghai Foreign Language Education Press, 1970.

[3]. Cao Guihua. A Contrastive Study of English and Chinese passive sentences [J]. Journal of Xiaogan University, 2010:30.

[4]. Dai Weidong, Wang Dong. The Study of Language Transfer: Problems and Thinking [J]. Foreign Language, 2002(6):1-9.

[5]. Fu Xiaoping. On the application of Transfer Law in English Teaching [J]. Courses• Teaching Materials• Teaching Methods, 2003(2):33-37.

[6]. Liu Chang, Cheng Bangxiong. The Study of Mother Tongue Transfer: Looking Back and Thinking [J]. Journal of Jianghan University (Humanities Edition), 2012(31).

[7]. Lian Shuneng. On the Basic Features of English and Chinese Syntax [J]. Journal of Xiamen University, 1992(3).

[8]. Sun Li. A Study of Developing Second Language Acquisition [J]. Modern Foreign Language, 2005(2): 24-27.

[9]. Xue Yulong. Contrastive Linguistics [M]. Shanghai: Shanghai Foreign Language Education Press, 2010. 